\title{
DEGREE OF COMPLIANCE WITH PUBLIC CONSULTATION FOR AWARDED WIND TURBINE CONTRACTS UNDER LRP I PROCESS
}

\author{
by \\ Sophie Boucher \\ B.A. (Hon.), Laurentian University, 2015 \\ A Major Research Paper \\ presented to Ryerson University \\ in partial fulfillment of the requirements for the degree of \\ Master of Planning \\ in \\ Urban Development
}

Toronto, Ontario, Canada, 2017

(C) Sophie Boucher 2017 


\section{Author's Declaration for Electronic Submission of a MRP}

I hereby declare that I am the sole author of this MRP. This is a true copy of the MRP, including any required final revisions.

I authorize Ryerson University to lend this MRP to other institutions or individuals for the purpose of scholarly research.

I further authorize Ryerson University to reproduce this MRP by photocopying or by other means, in total or in part, at the request of other institutions or individuals for the purpose of scholarly research.

I understand that my MRP may be made electronically available to the public. 


\title{
DEGREE OF COMPLIANCE WITH PUBLIC CONSULTATION FOR AWARDED WIND TURBINE CONTRACTS UNDER LRP I PROCESS
}

\author{
(C) Sophie Boucher, 2017 \\ Master of Planning \\ in \\ Urban Development \\ Ryerson University
}

\begin{abstract}
Municipalities and residents criticized the planning process for large-scale wind energy projects imposed on them under the Green Energy Act, 2009 (GEA). As such, the Ontario government promised improvements in public engagement, and the FIT policies were replaced by the Large Renewable Procurement (LRP) process. To determine the compliance with the Independent Electricity System Operator's engagement process under the LRP I, interviews with municipal planners and abutting landowners were conducted, and document information was reviewed. The key findings of this study include: 1) the final results did not support increased engagement statements made by both, former Minister of Energy Bob Chiarelli and Premier of Ontario Kathleen Wynne, as the majority of projects were awarded a contract without municipal support or abutting landowner support; and 2) all developers conducted mandatory consultation; however, the majority failed to truly engage with all stakeholders who would be the most affected by the project.
\end{abstract}

Key words: Large Renewable Procurement process; Consultation; Wind Energy; LargeScale Wind Projects 


\section{Acknowledgments}

I would like to take this opportunity and thank my MRP supervisor, Dr. Ron Pushchak for all of the help and guidance he has provided me throughout this process. I would also like to thank Dr. Dan McGillivray, for being my second reader.

I am also thankful to all participants who took the time to complete an interview with me. Their time and feedback was greatly appreciated.

This paper would not have been possible without the support I have received from my family. I would like to thank my parents for always encouraging me to pursue my goals, and a special mention goes out to my loving fiancé, Thomas Hautot, who has been my rock throughout my master's degree. 


\section{Table of Contents}

Author's Declaration for Electronic Submission of a MRP..............................ii

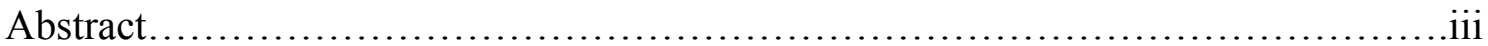

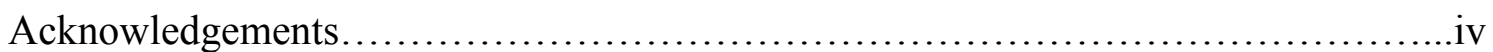

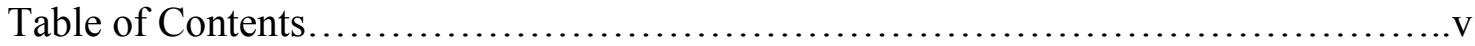

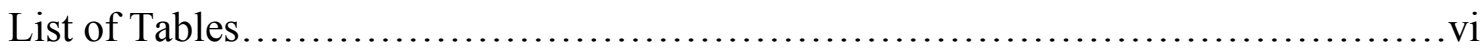

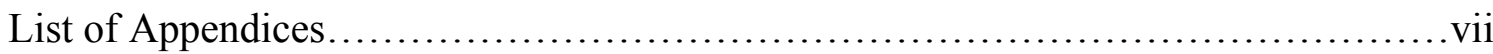

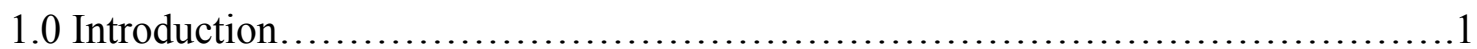

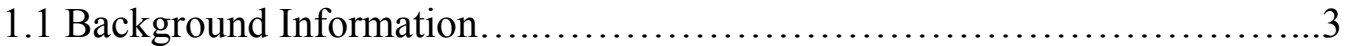

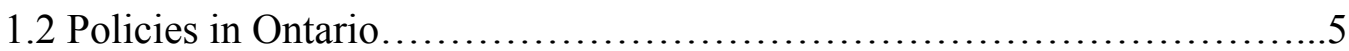

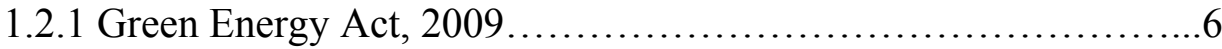

1.2.2 Renewable Energy Approval Process.............................6

1.2.3 Feed-In Tariff Program.......................................6

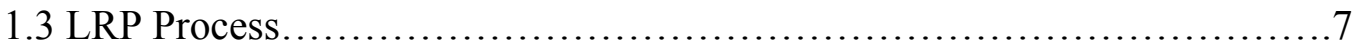

1.3.1 Request for Qualifications................................... 8

1.3.2 Request for Proposals.........................................

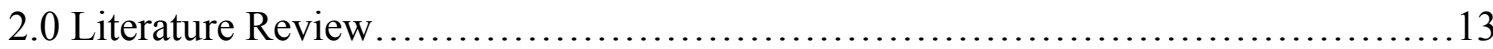

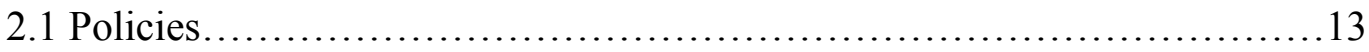

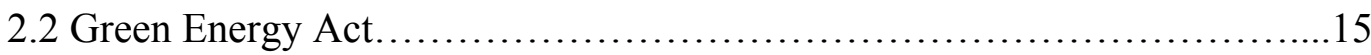

2.3 Benefits \& Impacts....................................................... 17

2.4 Consultation During the Development of Wind Energy Projects..............18

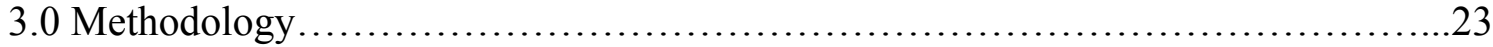

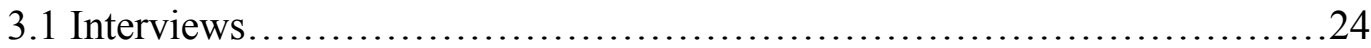

3.1.1 Selection Process...........................................24

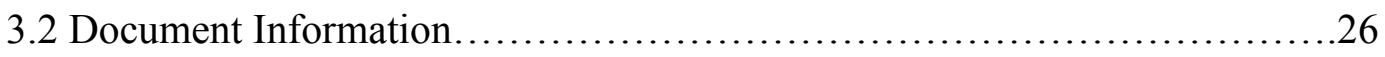

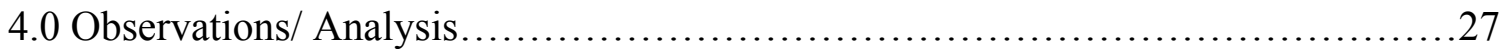

4.1 On-Shore Wind Energy Proposals........................................27

4.2 Five Awarded Large-Scale Wind Energy Projects.............................31

4.3 Interviews and Document Information on Consultation during LRP I.........34

4.3.1 Results - Interviews with Abutting Landowners.............35

4.3.1.1 Consultation Process...............................36

4.3.1.2 Effects of Project................................37

4.3.1.3 Opinion about the Project..........................37

4.3.2 Results - Interviews with Municipal Planners................38

4.3.2.1 Consultation Process................................39

4.3.2.2 Effects of Project................................39

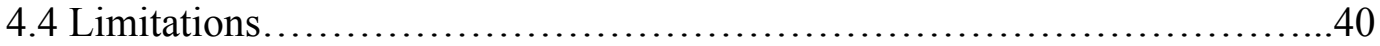

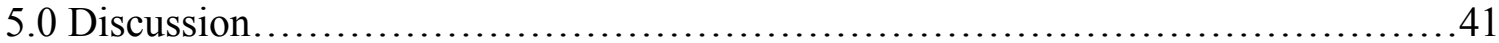

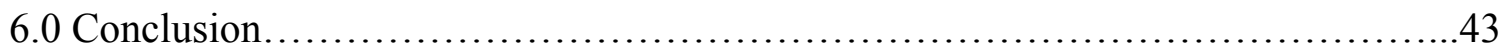

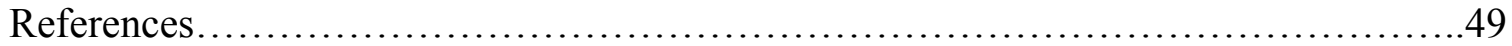




\section{List of Tables}

Table 1: Rated Criteria Point System........................................ 11

Table 2: General Information about Awarded Projects............................ 27

Table 3: On-Shore Wind Proposals.............................................28

Table 4: Rated Criteria Point System Results for Awarded Projects...................32 


\section{List of Appendices}

Appendix A: Interview Questions for Municipal Planners...........................46

Appendix B: Interview Questions for Abutting Landowners........................48 


\subsection{Introduction}

In 2009, the Ontario liberal government implemented the Green Energy and Green Economy Act, 2009 now commonly known as the Green Energy Act (GEA). The GEA streamlined the approvals process for large-scale renewable energy developments in the Province, and developed feed-in tariff (FIT) policies, which had no requirements for developers to consult with local municipalities or their residents (Province of Ontario, 2015). The Province implemented the GEA to rapidly increase the development of largescale wind energy projects, and removed local planning powers that might be used to stop them from being built, as confirmed by the former Premier of Ontario Dalton McGuinty when he said that "Municipalities will no longer be able to reject wind turbines $\cdots$ because they don't like them" (Leslie, 2009). The GEA amended over a dozen Provincial Acts including the Planning Act, which meant that municipalities were no longer able to use tools under this Act for siting or approving large-scale renewable energy projects, including: 'Official Plans', 'Zoning By-Laws', 'Demolition Control Areas' or 'Development Permit Systems' (Manning \& Vince, n.d.). This meant that municipal planners were no longer able to determine where or if industrial wind turbines could be located in their municipality. It was also clear that traditional local public consultation was curtailed.

When municipal planners are responsible for such projects, they are required to consult with all stakeholders that would be affected by the final decision, including residents. This is emphasized in the Canadian Institute of Planners Statement of Values, in the Professional Code of Practice. Planners are required to have meaningful public participation with everyone who may be affected by the decision, and ensure that all voices are heard (Ontario Professional Planners Institute, n.d.). 
The implementation of the GEA and the FIT policies to rapidly increase the supply of renewable energy in the Province did not come without opposition from municipalities and their residents. Currently, there are 92 municipalities across the Province that have declared themselves an 'unwilling host' to industrial wind turbines, and several have also expressed broader concerns regarding the new process for approving wind energy developments in the GEA (TerraMetrics Map Data, 2017). Residents have also expressed concerns regarding the planning and development of wind energy projects in the Province. Currently, there are two main wind opposition groups in Ontario: Ontario Wind Resistance and Wind Concerns Ontario, that have also opposed the GEA (Stokes, 2013). There have also been smaller opposition groups formed in municipalities where a large-scale wind energy project has been proposed. During the LRP I process, a few small opposition groups were formed, including: Dutton-Dunwich Opponents of Wind Turbines; Concerned Citizens of North Stormont; and Save the Nation. These opponent groups did not necessarily oppose wind projects, but opposed the process, as expressed by Save The Nation when they stated that they are opposed to wind projects that are "imposed to citizens and communities without consultation and against their will" (Save The Nation, n.d.).

Concerns and criticisms about the new process were expressed to the Province, which then directed the Independent Electricity System Operator (IESO) in 2013 to replace the large FIT policies (a fixed-price policy) with a new competitive bidding process, known as the Large Renewable Procurement (LRP) process (Pushchak et al., 2016). The LRP process would have a component requiring early consultation with municipalities, residents and Aboriginal communities that would be affected by the 
project and an optional consultation component that would serve as an incentive for developers to accomplish more in depth consultation with these stakeholders in order to receive their support for the project.

In order to reassure municipalities, the former Minister of Energy Bob Chiarelli expressed that it would be "virtually impossible" for a community to be awarded a contract without municipal support (Legislative Assembly of Ontario, 2013), and continued by adding that "it will be almost impossible for somebody to win one of those bidding processes without an engagement with the community" (Legislative Assembly of Ontario, 2013). Unfortunately, the results of the LRP I process did not support these statements, as only two of the five awarded large-scale wind energy projects that were awarded a contract under the first round of the Large Renewable Procurement (LRP I) process received municipal support (Independent Electricity System Operator, 2016b).

\subsection{Background Information}

Wind energy has become an important source of energy worldwide, as its production around the world has grown very rapidly. This was demonstrated between 2010 and 2015 when the world increased over half of its wind power capacity in this timeframe (REN21, 2016). One reason that wind energy has been rapidly increasing is that countries have recently begun harnessing wind energy to produce electricity to meet carbon reduction targets; however, some countries have been utilizing wind for centuries. Egyptians were harnessing wind energy as early as 5,000 years ago for sailboats and China used wind energy to pump water as early as 2,000 B.C. (LMWindPower, n.d.; Wind Energy Foundation, 2016). Iran was the first country to build wind turbines, and these were redesigned in Holland, and between the eleventh and twentieth centuries wind energy 
was harnessed for various purposes including food production (LMWindPower, n.d.; Wind Energy Foundation, 2016).

In 2015, Canada was one of the top ten leading countries in wind energy electricity development (REN21, 2016), with over 10,000 megawatts (MW) of installed wind power capacity, providing enough electricity to power over three million houses (CANWEA, n.d. d). The leading Province in Canada is Ontario, and it has only recently harnessed wind power from large-scale wind energy projects. By the end of 2016, it had over 4,700MW of installed wind power capacity (CANWEA, n.d. c), representing over forty percent of total installed capacity in the country. Prior to producing energy through wind, the Province heavily relied on coal, which was found to be detrimental to the environment (Ontario Public Health Association, 2002).

In 2003, the Province had over 7,000MW of installed power produced by coal, with no installed wind power capacity (Ministry of Energy, 2015). At that time, the liberal government promised to shut down coal fired plants by 2007 (Rowlands, 2007). After the liberal government came into power in 2003, the production of coal began to decline and the production of renewable energy sources began to increase. In 2014, the liberal government eliminated the production of energy from coal, and the Province had installed over 3,500MW of wind power (Ministry of Energy, 2015).

If projections made by the Ministry of Energy for the year of 2032 are correct, the Province will have around 6,500MW of installed wind power capacity. To increase wind power production in the Province, policies have been implemented that have supported this direction. Recently, the Province awarded five large-scale wind energy contracts under the LRP I with a total of 299.5MW (Independent Electricity System Operator, 
2016b), they are: 1) Romney Wind Energy Centre; 2) Otter Creek Wind Farm; 3) Nation Rise Wind Farm; 4) Strong Breeze Wind Project; and 5) Eastern Fields Wind Project.

A total of sixteen contracts were awarded under the LRP I process, including: five large-scale wind energy contracts, seven solar contracts, and four waterpower contracts with a combined total of 454.885MW (Independent Electricity System Operator, 2017). When the Province directed IESO to replace FIT policies with the LRP, measures were put in place to encourage developers to consult with municipal officials, residents and Aboriginal communities prior to receiving a contract (Independent Electricity System Operator, 2015). These measures included a required consultation component, and an optional public engagement component. Consultation was meant to be an important component of the LRP I process, therefore, this study sought to determine the degree of compliance with the IESO's public engagement process under the LRP I for the five awarded large-scale wind energy projects and will also briefly touch upon the benefits and impacts that these projects may have on municipalities and their residents.

In order to provide additional background, the next two sections will briefly explain the central policies/ programs that were introduced in Ontario that have influenced energy production, and will describe the LRP process in greater detail.

\subsection{Policies in Ontario}

Central policies in Ontario have influenced energy production, they include the Green Energy Act, 2009 and the FIT policies developed in the GEA. This section will briefly discuss the GEA and the FIT policies, and the LRP process will further be explained in Section 1.3. 


\subsubsection{Green Energy Act, 2009}

The GEA allowed the Province to streamline the approvals process for renewable energy developments, through the Renewable Energy Approval (REA) process (Ontario Regulation 359/09), and municipalities were no longer permitted to use the Planning Act to control where wind turbines could be developed (Province of Ontario, 2015). The REA was one of two approvals processes for renewable energy projects in the Province; the other was the Class Environmental Assessment requirement (Province of Ontario, 2015). All five large-scale wind energy projects that were awarded a contract under the LRP I process were required to get an REA approval before they could begin the construction phase of the project. Currently, all five projects have begun this process.

\subsubsection{Renewable Energy Approval Process}

The Ministry of the Environment and Climate Change is responsible for approving renewable energy projects through the REA process (Province of Ontario, 2015). This process ensures the protection of residents, by setting requirements and standards for projects. For large-scale wind energy projects, requirements include, but are not limited to: the maximum noise level turbines could produce, minimum setback distances from buildings, roads, railways, etc., and two mandatory public meetings (Province of Ontario, 2015).

\subsubsection{Feed-In Tariff Program}

The FIT policies introduced through the GEA, were meant to encourage the development of new renewable energy projects in the Province. There were two separate FIT programs: 1) FIT (for projects over ten kilowatts $(\mathrm{KW})$ ) and 2) microFIT (for projects of ten KW or less) (Ontario Power Authority, 2010), allowing a wide variety of applicants to apply for a contract, including: homeowners, municipalities and Aboriginal 
communities. At the time, the average for conventional sources of energy was around 8 cents/kWh (Ontario Energy Board, 2016), whereas the FIT contract price for on-shore wind projects was 13.5 cents/kWh (Ontario Power Authority, 2010), which represented a high financial benefit for developers to apply for a contract under FIT. In the first ten months of implementation, the Province had received over 16,000 FIT applications (Pushchak et al., 2016), which allowed for a rapid increase in wind energy production in the Province.

Consultation with municipalities, Aboriginal communities and residents was recommended in the FIT 1 (2009-2011) program; however, it was not required (Province of Ontario, 2015). The FIT 2,3 and 4 programs (2012-present), also recommended consultation with municipalities, and Aboriginal communities, but was not required; however, priority was given to projects that either had municipal or Aboriginal support, and/or had conducted at least one public meeting in a project's host municipality (Province of Ontario, 2015).

FIT policies were known to be the most common renewable energy policy in many countries; however, in recent years, the competitive bidding process has become very popular in different countries, including Canada (REN21, 2016). In Ontario, LRP I, a competitive bidding process was introduced in 2014 and contracts were awarded in March of 2016. The LRP II was launched in 2016, but was cancelled shortly after.

\subsection{LRP Process}

In 2014, IESO, under the direction of the Ontario liberal government, replaced the FIT program for large-scale energy developments over 500 kilowatts (KW), with a competitive bidding process known as the Large Renewable Procurement process 
(Ministry of Energy, 2017). Under the LRP I process, the Province sought 300MW of onshore wind energy, and received submissions for over 2,000MW of on-shore wind energy proposals (Independent Electricity System Operator, 2016a), demonstrating the interest that developers had in receiving a contract under the LRP I.

The LRP process was meant to follow principles, procurements and timelines provided in the Ontario Long Term Energy Plan, 2013. Two of the six guiding principles of the LRP process were to:

1) Engage early and regularly with local and Aboriginal communities; and

2) Occur in multiple successive rounds, providing opportunity for diverse set of participants (Government of Ontario, 2013).

In the LRP I process, municipalities were supposed to have a stronger voice in decisionmaking, as they would be consulted in the early stages of the planning phase, and contracts were supposed to provide better value for residents (Province of Ontario, 2015) because there was a price cap set for each type of renewable energy in order to bring prices down (Independent Electricity System Operator, 2016a). In the LRP process, applicants were required to submit a Request for Qualification (RFQ), and if qualified, would need to submit a Request for Proposal (RFP) of their proposed project.

\subsubsection{Request for Qualifications}

To be eligible to submit an on-shore wind proposal in the RFP, proponents were required to qualify under the RFQ. Developers had to demonstrate to the IESO that they had previous experience with renewable energy projects and had the financial capability to build the project (Independent Electricity System Operator, 2017).

There were forty-two applicants who were qualified to submit proposals under the RFP process. Of these applicants, twenty-one were qualified having both financial 
resources and experience to provide on-shore wind energy proposals (Independent Electricity System Operator, 2015a). For the most part, the qualifications favoured large international wind energy developers.

\subsubsection{Request for Proposals}

During the RFP, qualified applicants submitted a total of 103 project proposals, including twenty-seven on-shore wind energy proposals (Independent Electricity System Operator, 2015b). Of these, five were awarded a contract under the LRP I process.

The RFP consisted of four stages (Independent Electricity System Operator, 2015). During the first stage, IESO needed to ensure that the application was completed (forms were filled out and payments were made). If deemed to be complete, it was moved to the second stage. During this stage, IESO ensured that the application met all of the mandatory requirements, such as: the submission of a Community Engagement Plan, the effort to have a meeting with the host municipalities of the project, and to hold at least one public meeting in each project host municipality. If these requirements were not met, the proposal would have been rejected. If the proponent had successfully completed these requirements, the application would have advanced to the third stage, which was an optional stage.

Here, the proposals were given rated criteria points, but only if the developer had received support from host municipalities, abutting landowners and/or Aboriginal communities by conducting additional community engagement actions. As this stage was optional, the developer was not required to conduct additional consultation with municipalities, residents or Aboriginal communities to receive a contract. Since the former Minister of Energy did state that projects would not likely be given a contract if 
they did not receive municipal support, the expectation was raised that the rated criteria point system would have had significant impact on the evaluation of proposals, to ensure that only projects that have received municipal support would have been awarded a contract. As results have demonstrated, projects that had not received municipal support were still awarded a contract.

To receive a contract, there was required consultation that developers had to do, but there were also incentives provided for them to conduct additional consultation activities with municipalities, Aboriginal communities and abutting landowners to receive their support up to 100 points. Developers could receive up to 80 points for community engagement, which included: receiving municipal support, achieving a municipal agreement and/or receiving support from at least 75 per cent of abutting landowners. Abutting landowners are defined by IESO as landowners who are either located next to a property that had leased a portion of their land for an industrial wind turbine or located next to a property on which the proposed connection line would be installed (Independent Electricity System Operator, 2015). Therefore, residents who are living very close to the wind turbines and those who may be living further away can have the same impact on the final decision.

Developers would also receive up to 20 points for Aboriginal consultation, if they had consulted with Aboriginal communities who were either affected or interested in the project. The Aboriginal community also needed to have at least ten percent interest in the project, through a shared ownership agreement (Ministry of Energy, 2017). If a developer had successfully met all of the components for community engagement and Aboriginal participation they would have received 100 points, and if they had only met certain 
components, they would have received fewer points, as demonstrated in Table 1 - Rated Criteria Point System. There were two different point systems, one for projects that were entirely located on Crown Land, and the other for those that were not. As the five awarded large-scale wind projects were not entirely located on Crown Land, Table 1 only represents the components and number of points allocated for projects that were not entirely located on Crown Land.

Table 1 - Rated Criteria Point System

\begin{tabular}{|c|c|c|c|c|}
\hline & $\begin{array}{c}\text { Municipal } \\
\text { Council Support } \\
\text { Resolution }\end{array}$ & $\begin{array}{c}\text { Municipal } \\
\text { Agreement }\end{array}$ & $\begin{array}{c}\text { Abutting } \\
\text { Landowner } \\
\text { Support (75\%) }\end{array}$ & $\begin{array}{c}\text { Provincial } \\
\text { Crown Land } \\
\text { Leaseholder } \\
\text { Support (75\%) } \\
\text { (If Applicable) }\end{array}$ \\
\hline 80 Points: & $\mathrm{X}$ & $\mathrm{X}$ & $\mathrm{X}$ & $\mathrm{X}$ \\
\hline 50 Points: & $\mathrm{X}$ & $\mathrm{X}$ & $\mathrm{X}$ & $\mathrm{X}$ \\
\hline 40 Points: & & $\mathrm{X}$ & $\mathrm{X}$ \\
\hline 30 Points: & & $\mathrm{X}$ & & \\
\hline 10 Points: & & & & \\
\hline
\end{tabular}

(Ministry of Energy, 2017)

The fourth and final stage was evaluation and selection. During this stage, IESO evaluated all projects and selected the ones that would be awarded a contract. Evaluation was supposed to be based on two main factors: 1) the proposal price and 2) the capacity available on the grid at the location proposed to connect to it (Ministry of Energy, 2017); however, IESO had not provided any information on how they evaluated proposals. The decision process was not explained, therefore, the importance of the proposal price, the capacity at the grid, or the rated criteria points in the evaluation process is not known. 
The optional rated criteria point system was created as an incentive for developers to conduct additional consultation with municipalities, abutting landowners and Aboriginal communities. It was considered an incentive because if developers had successfully engaged with these stakeholders, and received their support/ agreements for the project, their evaluated proposal price would have been lowered. The more points a developer had received, the lower their evaluated proposal price would have been, since these points would have reduced the price (Independent Electricity System Operator, 2015). The points were only able to impact the evaluated proposal price by 40 per cent, the other 60 per cent of approval was due to other factors which were previously mentioned: their bid price and the capacity at the grid (Independent Electricity System Operator, 2015; Pushchak et al., 2016). Therefore, if a developer had not applied for criteria points, but had proposed a lower bid price, they would have been eligible to receive a contract.

The LRP I process provided developers with the opportunity to conduct meaningful consultation at the beginning of the development process with stakeholders who would be most affected by the project, by imposing required consultation and by giving incentives through the optional point system to encourage developers to conduct additional consultation that would result in support for the project. The results of the awarded large-scale wind energy projects demonstrated that an optional point system was not an effective method of generating support, as the majority of projects were awarded without having either municipal or abutting landowner support. Only one project was awarded a contract which received both municipal and landowners support, as shown on Table 4 - Rated Criteria Point System Results for Awarded Projects. 


\subsection{Literature Review}

Several countries have been increasing their supply of renewable power, allowing wind energy to become an important source of energy worldwide. Countries have been able to increase their supply of electricity through large-scale wind energy projects. Since they are relatively new to many countries, including Canada, planning for these projects has not come without opposition. As such, there have been many studies completed on the development of large-scale wind energy projects (Hindmarsh, 2010; Pepermans \& Loots, 2013; Ohl \& Eichhorn, 2010). As my study focuses on determining the degree of compliance with the IESO public engagement process, and the effects (positive and negative) that these projects may have on municipalities that were awarded a contract, this literature review will be grouped into four different themes: 1) Policies; 2) Green Energy Act; 3) Benefits and Impacts; and 4) Consultation During the Development of Wind Energy Projects.

\subsection{Policies}

The Government of Ontario has put in place two sequential policies that have affected wind energy development in the Province, the Feed-In Tariff policies (fixed-price) and the Large Renewable Procurement process (competitive bidding). Studies in this section will review different policies that have been implemented in Ontario between 1990's and the present.

Rowlands (2007) researched the growth of renewable energy in the Province of Ontario between 1995 and 2006. During this timeframe, there were two major policy changes that affected wind energy in Ontario. The first was made in 2003 when the conservative government implemented a Renewable Portfolio Standard, requiring a certain percentage of renewable energy to be provided from all energy providers. The 
second happened in 2006 when the liberal government determined that FIT policies should supplement the existing bidding process that was already in place (Rowlands, 2007).

Mabee, Mannion, \& Carpenter (2012) compared FIT policies in Ontario with those established in Germany. FIT policies in Germany used a degression model, which made electricity prices decline over time, which could further be explored by Ontario. Ontario could also look at expanding the range of technologies promoted under FIT. FIT policies in Ontario, have been known to highly encourage a few sources of energy, such as wind and solar, whereas Germany's policies have been known to encourage a wider range of renewable energy sources, including biomass (Mabee et al., 2012).

Stokes (2013) published a study regarding the political aspects of the FIT policies in Ontario between 1997 and 2012. Two conclusions of this study were: 1) even though a large number of people may be in favour of a policy, that does not mean that the implementation of that policy would be readily accepted by the local residents who would be affected by it; and 2) the price that is set by governments for FIT policies should be flexible, and have the opportunity to decline over time (Stokes, 2013).

Pushchak, Carter-Shamai, Golovkin, Holmes, Jensen, Mathuria, Wilson \& Windross (2016) explored the economic and political decisions which led to the adoption of the large FIT policies and the LRP process in Ontario. The Province had received local community complaints regarding their FIT policies, leading to the creation of the LRP process. This paper also explored whether the complaints received about the FIT policies were addressed within the LRP process. The authors observed sixteen different proponents, and reviewed a total of 124 different wind projects/ proposals. This study 
concluded that by "replacing FIT with LRP, the Ontario government chose continued expansion of its large wind projects and the reduction in renewable energy costs over meaningful engagement" (Pushchak et al., 2016, p.10).

\subsection{Green Energy Act}

The Green Energy Act, 2009, took away the power from municipalities over siting and approving renewable energy projects in the Province of Ontario (Christidis \& Law, 2012). Several studies have demonstrated problems that resulted from the implementation of the GEA, in relation to the development of large-scale wind energy projects.

Christidis \& Law (2012) examined the Green Energy Act, 2009 and residents' perceptions and complaints about wind energy projects. This study determined that the annoyance and health concerns raised by residents who live close to wind energy projects could be related to the planning process of wind energy projects. The authors recommended that the Province incorporate a collaborative planning approach for largescale wind energy projects, as residents may have fewer concerns if they were involved in decision-making (Christidis \& Law, 2012).

Fast \& Mabee (2015) examined the effects that policy can have on the acceptance of wind projects. The authors evaluated five different case studies, one of which was approved before FIT, under the Request for Proposals program, while the other four were approved under the FIT policies under the GEA. The authors conducted 40 interviews with opponents, supporters, developers, municipal planners, and landowners who had leased their land for wind turbines. This study determined that the removal of municipal planning power over the development of large-scale wind energy projects had an impact on how residents perceived these projects, for example: trust was diminished in the 
process, and municipalities began to declare themselves 'unwilling hosts' (Fast \& Mabee, 2015).

Songsore \& Buzzelli (2015) examined Ontario newspaper articles between 2002 to 2010 , to determine the driving factors either for support or opposition to large-scale wind energy projects in the Province. The results demonstrated that people are not usually opposed to the construction of the wind turbines themselves; they are generally opposed to the decision process. In newspapers written after 2009, after the implementation of the GEA, there was seen to be a growth in resistance to large-scale wind energy projects, and people began to hold rallies to oppose them. The authors noted that there is a "need for increased procedural justice through public engagement" in the planning process, and they recommended that this should be done through local planning (Songsore \& Buzzelli, 2015).

The GEA has faced opposition from both municipalities that began declaring themselves 'unwilling hosts' to industrial wind turbines and from their residents who were opposed to these projects being built in their municipality and have raised concerns about the wind projects affecting their health. The literature suggested that when people are involved during the planning process, they are more likely to accept the project. Several studies have recommended collaborative planning and local planning as a means to achieve it. The importance of consultation during the development of large-scale wind energy projects will further be explored in Section 2.4 . 


\subsection{Benefits \& Impacts}

Large-scale wind energy projects can create potential benefits but can also produce negative impacts for municipalities. Benefits that a municipality could receive, have been explored in several articles and websites including the Canadian Wind Energy Association's website. There are different benefits that municipalities could receive; they include: economic (monetary) benefits for the whole community (for example: the developer could provide the municipality with a Community Vibrancy Fund, they could pay property taxes and the municipality could own a portion of the project by entering into a shared ownership with the proponent) and for specific landowners (for example: proponents could decide to enter into land-lease payments with landowners who agreed to lease a portion of their land for a wind turbine or they could decide to provide a one time payment offer to abutting landowners for their support of the project, as explained by an interviewee). There are also increased opportunities for the community, for example: these developments could provide temporary and permanent job opportunities for the local residents, and the proponents could also buy materials they need for the project within the local host municipalities (Armeni, 2016; Environmental Defence, 2016; CANWEA, n.d. b). The development of large-scale wind energy projects has also been represented in literature as being a 'green' form of energy. Large-scale wind energy could produce worldwide environmental benefits, as it could reduce greenhouse gas emissions and preserve water (CANWEA, n.d. a).

These projects can also have significant negative impacts on municipalities and their residents. Wind energy is relatively new in the Province of Ontario, and as such, residents have raised many concerns. Those found in literature include: environmental concerns (for example: the impact on the populations of birds and bats), health concerns 
(the inability to sleep leading to fatigue, increase of headaches and earaches and the loss of concentration that could be caused by the increased level of noise from the turbines); turbine impacts on the visual landscape, and economic concerns regarding the increase of hydro rates (Armeni, 2016; Christidis \& Law, 2012; Groth \& Vogt, 2014).

Large-scale wind energy developments have the potential to create benefits and produce negative impacts in host municipalities. If people perceive the negative impacts outweighing the benefits, they may oppose a project. The next section will demonstrate the importance of consultation during the development of large-scale wind energy projects.

\subsection{Consultation During the Development of Wind Energy Projects}

Several articles have explored the importance of early consultation during the development of wind energy projects. Many focus on residents' perceptions of the consultation process during the planning of large-scale wind energy projects, and have proposed recommendations about how the consultation process could be improved.

Gross (2007), explored the relation between community fairness and local acceptance of a wind farm pilot study in the town of Taralga, New South Wales in Australia. The project divided the residents, as some were in favour of the project, and others were against it. Interviews with twelve residents, including supporters, opponents, and people with a neutral position were conducted to gain a better understanding of their thoughts about the consultation process. Many respondents did not consider being involved in a 'consultation process' rather they had simply been given information by the developers. Also, not all residents in the community had the same kind of communication with developers, which influenced their perception of the consultation process. Those 
who were directly contacted by the developer thought the process was fair, whereas, those who heard about the project at a later stage (including abutting landowners), did not perceive it to have been fair, which led to the formation of an opposition group (Gross, 2007).

MacLaren (2007) conducted eighteen wind facility siting case studies, seven in England, four in Wales, and seven in Denmark to determine the levels of public engagement during each planning process. The author performed interviews with municipal planners, developers, landowners, supporters and opponents of the wind projects. MacLaren determined that "projects with a high level of participatory planning are more likely to be publicly accepted and successful" (MacLaren, 2007, 2648), than others. MacLaren recommended a shared community model or cooperative ownership model for planning wind energy projects, to increase their acceptance (MacLaren, 2007).

Wright (2012) explored local opposition to wind projects in Atlantic Canada, where a large number of residents were in support of wind energy in general. During this study, the only required consultation was through the Environmental Assessment process, which occurred too late in the process for changes to be made to the project. Wright recommended that there should be more public engagement throughout the process, and suggested that residents' participation in the process could lead to increased acceptance (Wright, 2012).

Corscadden, Wile, \& Yiridae (2012) conducted an online survey of consultation efforts among community-owned wind projects in the Province of Nova Scotia. Respondents expressed that public engagement was very important in planning for largescale wind energy projects, but less important for smaller projects, such as a single wind 
turbine. They also expressed a need for early consultation, and they preferred receiving information through 'newspaper ads' and by attending 'public meetings' and preferred to provide feedback in person or via the Internet (Corscadden et al., 2012).

Brennan \& Van Rensburg (2016) examined public preferences for community consultation in Ireland. The authors surveyed thirty-six local residents from the West, the Midlands and the South Midlands of Ireland. Of the thirty-six surveyed residents, thirteen agreed to take part in a focus group. Everyone that participated emphasized that they would like "enhanced community consultation by way of more open, transparent and unbiased information, more influence on the wind farm development process and better representation of their needs and interests" (Brennan \& Van Rensburg, 2016, 357). This could be accomplished by having a community representative in the municipality that would foster communication between the developer and residents and provide them with information about the project (Brennan \& Van Rensburg, 2016).

Walker \& Baxter (2016) compared the perceptions of distributive economic justice in Ontario and Nova Scotia. These two provinces were chosen as they had different policies that could have an impact on how residents perceived the distributive results. Nova Scotia's policy that required a portion of a large-scale wind energy project to be owned by the community (community-ownership model), whereas in Ontario, the developer generally owned these projects. Walker \& Baxter conducted 54 interviews with residents, municipal officials, developers and policy experts for three different projects in Ontario, and six smaller wind projects in Nova Scotia (five were community-owned and one was owned by the developer). As wind projects in Nova Scotia were generally based on community ownership, the benefits were spread more evenly through the community, 
whereas in Ontario the majority of benefits were provided to specific landowners who had signed lease agreements with the developer. Overall, residents of Nova Scotia were happier with the planning process and siting of wind turbines than residents of Ontario (Walker \& Baxter, 2016).

Jami \& Walsh's (2016) article entitled Wind Power Deployment: The Role of Public Participation in the Decision-making Process in Ontario, Canada, is the closest to my own study. In this particular investigation, Jami and Walsh (2016) explored five wind projects that were approved under FIT to demonstrate existing public engagement within the Renewable Energy Approvals (REA) process, and how this engagement could be improved. The authors used secondary data for the project selection process, then examined project documents, attended public meetings, and conducted interviews with opponents, developers, municipal managerial planners, facilitators and consultants. One observation was that developers and residents had different thoughts about what was adequate public engagement. Developers generally held open house public meetings; however, these were not seen as adequate by the attendees. "In all interviews with the opponents, they claimed there was no avenue for public participation" (Jami \& Walsh, 2016, 13); and the process was found to simply be a "ticking of the box for the developers to show that they have conducted public consultation" (Jami \& Walsh, 2016, 13). The authors recommended that public engagement should take the form of collaborative planning with a third party knowledge broker who should be a part of the decision-making process (Jami \& Walsh, 2016).

Jami and Walsh (2016) conducted interviews with residents who were opposed to a wind project, with managerial planners and other stakeholders. These interviews were 
conducted to gain a better understanding of stakeholders' perceptions of the public engagement process during the REA process, for projects that had been approved under FIT. This study provided great insight into residents' and municipal officials' perceptions of the consultation process under the earlier REA; however, it did not address whether there was adequate consultation during the first round of the Large Renewable Procurement (LRP I) process. My study focused on determining the degree of compliance with the IESO's public engagement process during the recent LRP I. The LRP had replaced FIT to address criticisms that were made about the process, in which case, former Minister of Energy Bob Chiarelli declared that it would be "almost impossible" for a project to be awarded a contract without municipal support. The rated criteria points system in the LRP, although optional, were presented as a good opportunity for developers to fulfil at least one of the guiding principles: to consult early and regularly with municipalities (Government of Ontario, 2013). This study examined consultation during the LRP I process and examined how abutting landowners and municipal planners perceived it. It also briefly examined the effects (positive and negative) that these projects may have on municipalities where contracts were awarded. 


\subsection{Methodology}

This study conducted interviews with abutting landowners and municipal planners to gain a better understanding of the degree of compliance with the IESO public engagement process during the first round of the Large Renewable Procurement process, and to determine the potential effects (positive and negative) that these wind energy projects may have had on the project's host municipalities. Due to the timeframe of this study, only six interviews were conducted, therefore, the number of conducted interviews was statistically non-significant.

A total of five municipal planning departments were contacted, which resulted in two responses received. The initial goal was to interview five municipal planners. Although there were only two interviews completed, reports prepared for Council for two projects were provided by a planner who had refused to be interviewed, which helped answer a few questions. Municipal planners were asked a total of fifteen questions. See Appendix A: Interview Questions for Municipal Planners.

A total of twenty-three residents were contacted, resulting in four responses received. Three were with landowners who abut a property that was going to have an industrial wind turbine installed, and one was conducted with a landowner who was not considered an 'abutting landowner', but was located very close to the proposed project and identified themself as a landowner in the vicinity of the project who was going to be affected by the project. Abutting landowners were asked a total of ten questions. See Appendix B: Interview Questions for Abutting Landowners.

In addition to interviews, this study conducted an analysis of reports prepared for Municipal Councils, documents found on each awarded project's website, a report 
written to IESO by an opponent group, newspaper articles and a Freedom of Information Request from IESO.

The majority of the analysis focused on the five awarded large-scale wind energy contracts under the LRP I; however, to understand if consultation was an important part of the LRP I process, rated criteria points for twenty-three on-shore proposals were compared. There was a total of twenty-seven on-shore wind proposals submitted during the LRP I; however, due to the lack of publicly available information, only twenty-three proposals were compared. The Freedom of Information Requests were largely redacted and revealed little about the landowners contacted or the nature of their participation.

\subsection{Interviews}

Interviews were conducted with abutting landowners and municipal planners that were affected by a wind project that had been awarded a contract under the LRP I process. All participants who were interviewed have remained anonymous throughout the study. Prior

to recruiting abutting landowners and municipal planners, approval was received from the Ryerson Research Ethics Board.

\subsubsection{Selection Process}

Municipal planners selected for an interview were those who worked for a project host municipality and were aware of the wind project's file. To contact municipal planners, an online search was performed to contact the Planning Department in each municipality.

Interviews were also conducted with abutting landowners, who either live next to a property that would have an industrial wind turbine constructed, or next to a property that would host the proposed connection line. In the LRP I process, rated criteria points were awarded to projects that received support from at least 75 per cent of abutting 
landowners; however only two of five awarded projects accomplished this, as shown on Table 4. Interviews were conducted with abutting landowners to gain a better understanding of their perception of the consultation process, the effects that the awarded project had or may have on their community and their opinion about the project. In order to recruit abutting landowners, an online search was done to determine the location of the proposed industrial wind turbines and connection lines. This was done to identify properties that might be abutting landowners. A map search was conducted to determine the addresses and the abutting landowner's contact information. It was very difficult to obtain abutting landowners' contact information as it was not available on the project's websites and were not available in the Freedom of Information Request from IESO, as all of this information had been redacted.

To begin this process, information was retrieved from all five awarded projects' websites. The majority of the information provided on these websites only included general site boundary maps; they did not include the exact location of the wind turbines. Currently, most projects' websites do have maps that demonstrate the exact location of the proposed turbines; however, no addresses were found for these turbine locations. Once the general location of proposed turbines and the connection lines were found, this area was entered into Google Maps, to retrieve ranges of addresses, as all properties were located in rural areas, and to retrieve postal codes. These postal codes were then used in Canada 411 Reverse Lookup to retrieve contact information for addresses that either matched or were close to the range of addresses previously retrieved from Google Maps. As the addresses of the abutting landowners had not been provided in any document found on project websites or even in the Freedom of Information Request from the IESO, 
addresses that were found using Google Maps and Canada 411 Reverse Lookup were not all abutting landowners addresses. The only way this was confirmed was by calling the phone numbers that were retrieved.

Interviews were done to determine the degree of compliance with the IESO public engagement process during the LRP I process. These interviews allowed to gain a better understanding of whether the developers had simply conducted the required amount of consultation imposed on them, or went beyond this requirement and truly engaged municipalities and the residents who would be the most affected by the project. Abutting landowners were asked to provide their personal opinions regarding the consultation process during the LRP I, the effects that the project had or may have on their communities and their opinion regarding this project. Municipal planners were not asked personal opinions; instead, they were asked to provide their professional insight about the consultation process, the effects of each project and the municipality's position in regard to the project.

\subsection{Document Information}

In addition to interviews, information from other sources was also reviewed. This included: reports written to Council that were provided by a municipal planner; documents found on each of the awarded projects' websites; Ontario newspaper articles about the consultation process done during the LRP I; a report written by an opposition group, as the municipal planner refused to conduct an interview citing confidentiality concerns; and information provided in the Freedom of Information Request from IESO. 


\subsection{Observations/ Analysis}

There were a total of five wind projects that were awarded a contract under the LRP I

process. General information regarding these five projects is noted below in Table 2.

Table 2 - General Information about Awarded Projects

\begin{tabular}{|l|c|c|c|c|}
\hline Awarded Projects & $\begin{array}{c}\text { Host } \\
\text { Municipalities }\end{array}$ & Proponent & $\begin{array}{c}\text { \# of Proposed } \\
\text { Turbines }\end{array}$ & $\begin{array}{c}\text { Installed } \\
\text { Power } \\
\text { (MW) }\end{array}$ \\
\hline $\begin{array}{l}\text { Romney Wind } \\
\text { Energy Centre }\end{array}$ & $\begin{array}{c}\text { Municip. of } \\
\text { Chatham-Kent } \\
\text { and the Town of } \\
\text { Lakeshore }\end{array}$ & $\begin{array}{c}\text { EDF EN Canada } \\
\text { Development Inc. }\end{array}$ & $\begin{array}{c}\text { Up to } 20 \\
\text { turbines }\end{array}$ & 60 \\
\hline $\begin{array}{l}\text { Otter Creek Wind } \\
\text { Farm }\end{array}$ & $\begin{array}{c}\text { Municip. of } \\
\text { Chatham-Kent }\end{array}$ & $\begin{array}{c}\text { Renewable Energy } \\
\text { Systems Canada Inc. }\end{array}$ & 12 turbines & 50 \\
\hline $\begin{array}{l}\text { Strong Breeze } \\
\text { Wind Project }\end{array}$ & $\begin{array}{c}\text { Municip. of } \\
\text { Dutton-Dunwich }\end{array}$ & Invenergy LLC & $\begin{array}{l}\text { Up to } 20 \\
\text { turbines }\end{array}$ & 57.5 \\
\hline $\begin{array}{l}\text { Nation Rise Wind } \\
\text { Farm }\end{array}$ & $\begin{array}{c}\text { Municip. of } \\
\text { North Stormont }\end{array}$ & $\begin{array}{c}\text { EDP Renewables } \\
\text { Canada Ltd. }\end{array}$ & $\begin{array}{c}28-40 \\
\text { turbines }\end{array}$ & 100 \\
\hline $\begin{array}{l}\text { Eastern Fields } \\
\text { Wind Project }\end{array}$ & $\begin{array}{c}\text { Municip. of the } \\
\text { Nation and Twp. } \\
\text { of Champlain }\end{array}$ & $\begin{array}{c}\text { Renewable Energy } \\
\text { Systems Canada Inc. }\end{array}$ & $\begin{array}{l}\text { Up to } 10 \\
\text { turbines }\end{array}$ & 32 \\
\hline
\end{tabular}

(EDF, 2017; Otter Creek Wind Farm, 2017; Strong Breeze Wind Power Partnership, 2017; EDP Renewables, 2017; Renewable Energy Systems Canada Inc., 2017)

\subsection{On-Shore Wind Energy Proposals}

In order to determine the degree of compliance with the IESO's public engagement

process during the LRP I, twenty-three on-shore large-scale wind energy proposals that were submitted for evaluation during the LRP I process, including the five proposals that were awarded a contract, are noted in Table 3 - On-Shore Wind Proposals. This table demonstrates the number of rated criteria points that each proposal applied for, and the number of points that each proposal received. 
Table 3 - On-Shore Wind Proposals

\begin{tabular}{|c|c|c|c|c|}
\hline Name of Wind Project & Proposed Location & $\begin{array}{l}\text { Points } \\
\text { Applied for } \\
\text { Community } \\
\text { Engagement }\end{array}$ & $\begin{array}{c}\text { Points } \\
\text { Applied for } \\
\text { Aboriginal } \\
\text { Participation }\end{array}$ & $\begin{array}{l}\text { Number } \\
\text { of Points } \\
\text { Awarded }\end{array}$ \\
\hline † Gibaabik Wind Project 1 & $\begin{array}{l}\text { Crown land within Twp. of } \\
\text { Lockhart and Mulock }\end{array}$ & 80 & 20 & 100 \\
\hline Gibaabik Wind Project 2 & $\begin{array}{l}\text { Crown land within Twp. of } \\
\text { Lockhart and Mulock }\end{array}$ & 80 & 20 & 0 \\
\hline Clachan Wind Farm & Municip. of Chatham-Kent & 50 & 20 & 0 \\
\hline Duart Wind Farm & Municip. of Chatham-Kent & 50 & 20 & 0 \\
\hline Meadowvale Wind Farm & Municip. of Chatham-Kent & 80 & 20 & 0 \\
\hline † Victor Wind Project & Town of Lakeshore & 50 & 0 & 50 \\
\hline $\begin{array}{l}\text { Kruger Energy Chatham } \\
\text { Optima Wind Project }\end{array}$ & Municip. of Chatham-Kent & 80 & 0 & 0 \\
\hline † Blue Sky Renewable Fuel & Walpole Island First Nation & 0 & 20 & 20 \\
\hline $\begin{array}{l}*+\text { Strong Breeze Wind } \\
\text { Project }\end{array}$ & $\begin{array}{l}\text { Municip. of Dutton- } \\
\text { Dunwich }\end{array}$ & 30 & 20 & 50 \\
\hline † Erie Shores Wind Farm 2 & $\begin{array}{l}\text { Township of Malahide and } \\
\text { Municipality of Bayham }\end{array}$ & 80 & 20 & 80 \\
\hline † North Kent 2 & Municip. of Chatham-Kent & 50 & 0 & 50 \\
\hline South Branch II Wind Farm & Twp. of South Dundas & 0 & 0 & 0 \\
\hline *Nation Rise Wind Farm & Twp. of North Stormont & 0 & 0 & 0 \\
\hline Denbigh Wind Project & $\begin{array}{l}\text { Twp. of Addington } \\
\text { Highlands }\end{array}$ & 50 & 20 & 0 \\
\hline $\begin{array}{l}\text { Falconbridge Wind Farm } \\
\text { Project }\end{array}$ & City of Greater Sudbury & 50 & 0 & 0 \\
\hline $\begin{array}{l}* \text { † Otter Creek Wind Farm } \\
\text { Project }\end{array}$ & Municip. of Chatham-Kent & 50 & 20 & 70 \\
\hline $\begin{array}{l}\text { * Eastern Fields Wind } \\
\text { Project }\end{array}$ & $\begin{array}{l}\text { Municip. of The Nation and } \\
\text { Twp. of Champlain }\end{array}$ & 50 & 0 & 0 \\
\hline $\begin{array}{l}\text { Hardy Creek Wind Energy } \\
\text { Centre }\end{array}$ & $\begin{array}{l}\text { Middlesex and Lambton } \\
\text { Cos. }\end{array}$ & 0 & 20 & 0 \\
\hline $\begin{array}{l}\text { Northpoint I Wind Energy } \\
\text { Centre }\end{array}$ & $\begin{array}{l}\text { Township of North } \\
\text { Frontenac }\end{array}$ & 30 & 20 & 0 \\
\hline $\begin{array}{l}\text { Northpoint II Wind Energy } \\
\text { Centre }\end{array}$ & $\begin{array}{l}\text { Twp. of Addington } \\
\text { Highlands }\end{array}$ & 80 & 20 & 0 \\
\hline $\begin{array}{l}*+\text { Romney Wind Energy } \\
\text { Centre }\end{array}$ & $\begin{array}{l}\text { Municip. of Chatham-Kent } \\
\text { and Town of Lakeshore }\end{array}$ & 80 & 20 & 100 \\
\hline $\begin{array}{l}\text { † St. Isidore Wind Energy } \\
\text { Centre }\end{array}$ & Municip. of The Nation & 50 & 20 & 70 \\
\hline $\begin{array}{l}\text { Nauvoo Wind Power } \\
\text { Project }\end{array}$ & Twp. of Warwick & 0 & 0 & 0 \\
\hline
\end{tabular}

(Independent Electricity System Operator, 2016)

Legend :

* Five wind projects that were awarded a contract under the LRP I process

† Proposals that have been awarded rated criteria points 
As previously mentioned, there were twenty-seven on-shore large-scale wind energy proposals submitted to the IESO for evaluation during the LRP I process. Rated criteria point evaluations were released in October of 2016 through a Freedom of Information Request from IESO; however, these evaluations were only provided for twenty-three of the twenty-seven on-shore proposals. Therefore, the analysis has only consisted of the twenty-three wind proposals that were made available by IESO. Further, there was no information on how points were awarded or denied. There had also been no explanation provided by IESO on the reasons on why certain projects received contracts while others did not (they did not provide their reasoning for choosing the winning projects).

As IESO has not provided any explanation about their evaluation of proposals, some municipalities were left to wonder why they were not awarded a wind contract since they had provided their support, while others were left to wonder why they were awarded a contract since they had not provided support for the project. For example, the Municipality of Dutton-Dunwich, was awarded a project (Strong Breeze Wind Project) although it had not provided support for the project. Meanwhile, the Township of Malahide did not receive a contract, although it was in support of the Erie Shores Wind Farm 2 project, proposed in the township, and it had been awarded 80 rated criteria points as shown in Table 3. Although the breakdown of awarded points is left unknown for this project, the fact that the Mayor of the Township of Malahide stated that he was "shocked that a project proposed for Malahide was rejected while one was approved in DuttonDunwich" (Van Brenk \& Miner, 2016) demonstrates that the municipality was most likely in support of the project. The Strong Breeze Wind Project, which had only been 
awarded 50 points ( 30 points for having received at least 75 per cent of abutting landowners support and 20 for Aboriginal participation), had not been awarded any points for municipal support, as shown on Table 4.

Although Strong Breeze Wind Project received support from six different First Nations communities as shown on Table 4, these communities were all located over 1,000 kilometres $(\mathrm{km})$ away from the project (Bieman, 2016). The requirement for Aboriginal participation, as mentioned in Section 1.3.2 Request for Proposals, required developers to consult with Aboriginal communities that would either be affected or that were interested in the project in order to receive 20 rated criteria points. This requirement did not ensure local support for the project.

Of the twenty-three on-shore wind energy proposals, only two were awarded 100 points, the Gibaabik Wind Project 1 and the Romney Wind Energy Centre. The Romney Wind Energy Centre did receive a contract; however, the Gibaabik Wind Project 1 did not. This suggests that even if the rated criteria points were a required component of the LRP I, it did not mean that projects with higher points would have received a contract. In total, there were only nine of twenty-three proposals that were awarded any points, either for consultation or for Aboriginal participation. There were three proposals that did not apply for any rated criteria points: 1) the South Branch II Wind Farm, 2) the Nation Rise Wind Farm and 3) the Nauvoo Wind Power Project. Surprisingly, one of these proposals, the Nation Rise Wind Farm received a contract under the LRP I, although it had not applied for any points. That Nation Rise Wind Farm was able to receive a contract reinforced the fact that rated criteria points were an optional component of the LRP I decision. Therefore, developers were not required to get support or an agreement with 
project host municipalities, they were not required to get abutting landowner support, and they were also not required to get support from Aboriginal communities.

Of the five awarded wind contracts under the LRP I, only three were awarded rated criteria points: 1) the Strong Breeze Wind Project was awarded 50 points, 2) the Otter Creek Wind Farm Project was awarded 70 points and 3) the Romney Wind Energy Centre was awarded 100 points. The Nation Rise Wind Farm and the Eastern Fields Wind Project did not receive any points for community engagement or for Aboriginal participation. The fact that two projects were awarded a contract under the LRP I process without obtaining any points for public engagement suggests that this 'optional' consultation component might not been given as much weight in the evaluation of projects as other factors, such as the bid price.

\subsection{Five Awarded Large-Scale Wind Energy Projects}

In the LRP I process, the rated criteria points system, although optional, was supposed to increase the chances for proponents to receive a contract. Results of the point system for the five awarded contracts and the total points awarded are shown in Table 4.

As shown below on Table 4, two of five projects received $75 \%$ landowner/ leaseholder support, which means that more than half of awarded projects did not receive the support of at least $75 \%$ of abutting landowners, even with the very broad definition of an abutting landowner (either being located next to a wind turbine or next to the connection line). As shown on Table 2, there are a small number of turbines proposed for each project, and they will be spread out over a vast geographic area. It is possible that there would be more properties abutting the proposed connection line, than would abut the actual turbines, which means that people who may be located further away from the 
turbines (they may not be in sight), might have had the ability to impact the decisionmaking process.

Table 4 - Rated Criteria Point System Results for Awarded Projects

\begin{tabular}{|c|c|c|c|c|c|}
\hline Name & $\begin{array}{c}75 \% \\
\text { Landowner/ } \\
\text { Leaseholder } \\
\text { Support } \\
\end{array}$ & $\begin{array}{l}\text { Project } \\
\text { Community } \\
\text { Support }\end{array}$ & $\begin{array}{c}\text { Project } \\
\text { Community } \\
\text { Agreement }\end{array}$ & $\begin{array}{c}\text { Aboriginal } \\
\text { Participation }\end{array}$ & $\begin{array}{c}\text { Total } \\
\text { Points } \\
\text { Awarded }\end{array}$ \\
\hline $\begin{array}{l}\text { Romney } \\
\text { Wind } \\
\text { Energy } \\
\text { Centre }\end{array}$ & Yes & Yes & Yes & $\begin{array}{l}\text { Aamjiwnaang } \\
\text { First Nation }\end{array}$ & 100 \\
\hline $\begin{array}{l}\text { Nation Rise } \\
\text { Wind Farm }\end{array}$ & No & No & No & N/A & 0 \\
\hline $\begin{array}{l}\text { Strong } \\
\text { Breeze } \\
\text { Wind } \\
\text { Project }\end{array}$ & Yes & No & No & $\begin{array}{c}\text { Fort Severn, } \\
\text { Poplar Hill, } \\
\text { McDowell Lake, } \\
\text { North Spirit } \\
\text { Lake, Keewaywin } \\
\text { and Deer Lake } \\
\text { First Nations }\end{array}$ & 50 \\
\hline $\begin{array}{l}\text { Otter Creek } \\
\text { Wind Farm } \\
\text { Project }\end{array}$ & No & Yes & No & $\begin{array}{c}\text { Walpole First } \\
\text { Nation }\end{array}$ & 70 \\
\hline $\begin{array}{l}\text { Eastern } \\
\text { Fields Wind } \\
\text { Project }\end{array}$ & No & No & No & $\mathrm{N} / \mathrm{A}$ & 0 \\
\hline
\end{tabular}

(Independent Electricity System Operator, 2016b)

Two of five projects received community support, which means that more than half of projects did not receive the support of the host municipality. The reason that only two projects received Municipal support was because they were located in the Municipality of Chatham-Kent, a 'willing host' to industrial wind turbines. The other three projects, Strong Breeze Wind Project, Nation Rise Wind Farm, and Eastern Fields Wind Project were proposed to be located in municipalities that had declared themselves as 'unwilling hosts' to industrial wind turbines (TerraMetrics Map Data, 2017). As shown on Table 3, there were seven on-shore wind projects proposed in the Municipality of 
Chatham-Kent. The two projects awarded contracts had received the most rated criteria points of the projects proposed in Chatham-Kent, Romney Wind Energy Centre with 100 points, and Otter Creek Wind Farm with 70 points. One other proposal in Chatham-Kent received 50 points, while the other four were not awarded points. There was only one of five projects that had received a project community agreement, which means that a vast majority of the projects did not reach a community agreement with their host municipalities.

The Eastern Fields Wind Project, previously known as Parc éolien Gauthier, applied for 50 Community Engagement points as shown on Table 3, but did not receive any points, as shown on both Tables 3 and 4 . What is interesting about this particular project is that the proponent provided IESO with a copy of a Resolution of Support from both the Municipality of The Nation and the Township of Champlain in their proposal (Independent Electricity System Operator, 2016); however, they were not awarded any points. No explanation was given; therefore, this decision remains opaque. The following background information may explain why IESO did not award points for municipal support. In 2014, the Municipality of The Nation passed a resolution of support for the Parc éolien Gauthier project (Sauvons la Nation, 2015). In 2015, a group of citizens formed an opposition group called Save The Nation, and they convinced Council to pass a resolution declaring itself an 'unwilling host' to industrial wind turbines in August of 2015; but they had not cancelled their resolution for support of the Parc éolien Gauthier project. In mid-September of 2015 after the RFP submissions were provided to IESO, the Municipality of The Nation cancelled their support resolution for the project (Sauvons la Nation, 2015). In October of 2015, a few months before IESO declared the winning 
contracts, the opposition group wrote a report to IESO that explained the reasons they were opposed to the project, and asked them to reject the proposal (Sauvons la Nation, 2015). Since this report was submitted to IESO a few months before they had declared the winning contracts, there was an opportunity for this report to have played a role in the decision-making process.

\subsection{Interviews and Document Information on Consultation during LRP I}

To determine municipal planners and abutting landowners perceptions of the LRP I public consultation process, a total of six interviews were conducted. Three were conducted with abutting landowners, one with a landowner who was located in close vicinity of a project, and two with municipal planners. In addition to interviews, document information was also reviewed to determine the degree of compliance with IESO's public engagement process during the LRP I.

Details about public meetings held during the LRP I process were found on the projects websites, in newspaper articles and through interviews with abutting landowners. This search determined that all developers conducted the required minimum number of public meetings in host municipalities, which was one public meeting, and there was one developer who conducted an additional public meeting during the LRP I process, going beyond the consultation requirements. There were public meetings that were only attended by a small group of people; for example, one meeting had been attended by around twenty residents, whereas, another had been attended by over 250 people. There are different reasons that may have affected the number of people attending a meeting, such as the size of the population of the host municipalities and the time and the day that developers had chosen to hold their meeting. The first public meetings had all been held 
between May and August of 2015, only months or weeks prior to the RFP submission deadline and were usually held in the evening. Most public meetings were open houses with information displayed on several boards across the room. One public meeting had gone beyond this, and offered a presentation and conducted a period of questions and answers. During these public meetings, residents were shown the general site boundary of the project, but were not provided the exact location of wind turbines until the project had been awarded a contract.

The Premier of Ontario, Kathleen Wynne once said that large-scale wind energy projects would not be approved in municipalities where the majority of residents were against them (Sauvons la Nation, 2015), but the results of the winning contracts did not support this. For example: one municipality that was awarded a contract had conducted a survey (prior to the proposal receiving a contract), and determined that $84 \%$ of their residents were opposed to the project (Bieman, 2016). The fact that over half of the projects were awarded a contract without at least 75 per cent of abutting landowners support and more than half were awarded a contract without municipal support suggests that it did not really matter whether residents or municipalities approved or opposed a project.

\subsubsection{Results - Interviews with Abutting Landowners}

As previously mentioned, there were three interviews conducted with abutting landowners and one interview conducted with a landowner who was located in close proximity to a project, and will be subjected its potential effects. For the purpose of this study, all participants will be referred to as abutting landowners and interviewees. In order to keep participants' identities from being revealed, there will be no identifiable 
information in this study. Abutting landowners were asked ten questions pertaining to the consultation process, the effects and their opinion about the project.

\subsubsection{Consultation Process}

All interviewees indicated that they had not been consulted by the developer during the LRP I process. They also mentioned that there was at least one public meeting held during the LRP I process; however, not everyone had been able to attend. As the developers had not consulted them during this process, one interviewee reported that their neighbour notified them about being an abutting landowner, and another realized they could be an abutting landowner when they saw a general site boundary map on the Notice of Public Meeting in the newspaper. Interviewees who attended a public meeting during this process expressed some concerns about the format used by developers. One interviewee had not perceived the consultation to have been adequate; they said that the developer "had an open meeting and it wasn't a consultation, it was them telling us how great the industrial wind turbines were to be" and "there was no back and fourth". Another interviewee was surprised of the format used by the developer, as it was not what was expected, they said that people "thought it would be all rows of chairs, you would sit, they would do a presentation ... people from the floor could get up and ask questions and everyone could hear the same message. It was not that". Another concern raised by interviewees about the consultation process was that questions asked by residents were not adequately answered or had gone unanswered.

Some developers had used different forms of consultation to provide residents with information about the project, including a media campaign, by writing notices in the paper and by updating information on the project website. The majority of interviewees 
said that they were not able to voice their opinions or concerns through different consultation methods used by the developer. Only one interviewee said that they were able to voice their opinions or concerns on the project website.

\subsubsection{Effects of Project}

All interviewees expressed that they had not been provided with any benefit from the project, but they all had remaining concerns about the project. One concern that was discussed by everyone was the issue of hydro cost (interviewees expressed concerns about the rising cost of hydro and the Province giving too much money to the developers and then selling excess energy produced to the United States). Other concerns were: that neighbours were being torn apart, because these projects produced "bad feelings between neighbours", as some people were in favour of the project while others were not; the location of the project (concerns regarding how close certain projects were from residential areas which in their view was "terrible planning", some projects have led to geological concerns, and concerns about how some projects would destroy prime farmland); environmental concerns (impact on snake and turtle populations, a project had been proposed too close to wetlands, and concerns regarding the quality of water).

\subsubsection{Opinions about the Project}

For this component of the interview, interviewees were asked if they had been in favour of the project or against it at the beginning (prior to the project being awarded a contract). Two of the interviewees had been against the project from the beginning, due to concerns regarding the location of the project (one had been proposed too close to residential areas, and the other was going to destroy prime farmland). One interviewee had been neutral on the project, and the other did not provide their initial position. 
Interviewees also raised concerns about the planning process. One said that the project had been "badly implemented"; another expressed that it had been a very "dishonest process" as developers had not been always been truthful with residents; and another said that they thought the project could have been "handled much better, without so much animosity in the small towns against the wind companies". One interviewee had also raised concerns about the Green Energy Act, by stating: "I'm totally against the Green Energy Act, because it took away all our rights". This demonstrates that these abutting landowners were not necessarily opposed to a specific project, but they were opposed to the process and other factors such as the proposed location.

As only four interviews were conducted, the views are not representative of all five awarded wind projects. For one project, there were no abutting landowners interviewed; therefore, for that specific project, details about public meetings were discovered through information that was posted on the project website.

\subsubsection{Results - Interviews with Municipal Planners}

Details on the meetings that were held with municipal officials were discovered through reports written for Municipal Council, a report written to IESO, documents found on the projects' websites and through interviews with two municipal planners. Municipal planners had been asked a total of fifteen questions pertaining to their municipality's perceptions of the consultation process, the effects of the project and the municipality's position from the start of the project. 


\subsubsection{Consultation Process}

All developers made at least one presentation to council, but one made around two to four appearances at council during the LRP I process, as mentioned by a municipal planner. This municipal planner also said that it was the developer who had always requested to meet with municipal staff, either through informal phone discussions, an informal dropby session, and through presentations made to Council. The developer had consulted with the municipality to receive planning information and provided them with updates on the project.

\subsubsection{Effects of Project}

One benefit that municipalities can receive from the development of large-scale wind energy projects, as found in literature, is a community vibrancy fund (CVF). It is believed that all developers had discussed a CVF with host municipalities; however, some agreements had not yet been finalized, as it was too early in the process, as determined through interviews. Some developers may have finalized a CVF; however, this was not guaranteed. Other benefits that municipalities may receive from a project include: property tax revenue, local materials to be used during the construction of the project; and the possibility for several short term and a few permanent job positions.

The only concern that was raised by a municipal planner was about the LRP process. This municipal planner was concerned about this process and "how things are done at the Provincial level, and the fact that there is no municipal input besides the voting to support the project, to give it priority points". 


\subsection{Limitations}

There were two limitations in this study. The first was the lack of information that should have been made publicly available by the IESO and developers of the awarded projects. The developers did not release the exact geographic location of wind turbines until the projects were awarded a contract in the LRP I process. When the locations of the turbines were released, street addresses for the properties were not. Abutting landowners contact information could have also been retrieved from the Freedom of Information Request from IESO; however this information along with the majority of information in this request had been redacted. This made finding properties that were abutting landowners difficult.

The second was the willingness of municipal planners to be part of this study, as these projects have been controversial in municipalities that were awarded them. The initial goal was to conduct five interviews with municipal planners, however due to this limitation, only two interviews were conducted. The original goal was also to conduct twenty interviews with abutting landowners; however, due to the timeframe and the lack of publically available information resulted in three interviews conducted with abutting landowners and one interview with a landowner located very close and subject to the effects of the project. 


\subsection{Discussion}

Municipalities and residents raised concerns about the planning process of large-scale wind energy projects imposed on them under the GEA. As such, the Province promised improvements in public engagement and directed IESO to replace FIT policies with a competitive LRP bidding process. The LRP was supposed to provide municipalities with a greater voice in decision-making and provide more opportunity for developers to engage with them. To reassure municipalities and residents, the former Minister of Energy Bob Chiarelli and the Premier of Ontario Kathleen Wynne, both expressed that it would be very unlikely that projects would be awarded in municipalities that did not provide support for the project, or in municipalities where the majority of residents were opposed. However, the results of the awarded projects under the LRP I, have shown that although municipalities were not in support of a project or that residents were opposed did not seem to matter in the final decision.

The results of the large-scale on-shore wind energy contracts did not support the statements made by the former Minister of Energy Bob Chiarelli and the Premier of Ontario Kathleen Wynne. One project that had been awarded 100 points did not receive a contract; meanwhile, a project that had not even applied for points was awarded a contract. Of the five awarded contracts, only three had been awarded points, which means that two awarded projects had not received points. The majority of projects (three of five) had not received support from at least $75 \%$ of abutting landowners; the majority of projects (three of five) had not received community support; and the vast majority of projects (four of five) did not achieve a project community agreement. With these results, it appears that municipal support was not the most important criterion in the evaluation process. 
The LRP process was designed with a required consultation component and an optional public engagement component. This study suggests that all developers had conducted the mandatory consultation imposed on them during LRP I; however, the majority had failed to truly engage with all stakeholders that would be most affected by the project, including: municipal officials of each host municipality; abutting landowners and Aboriginal communities. This was discovered through interviews. All abutting landowners who had been interviewed said that the developer had not consulted them during the first round of the Large Renewable Procurement process. This demonstrates that the developer failed to engage with all abutting landowners. Also, both abutting landowners and municipal planners raised concerns about the planning process for largescale wind energy projects under the LRP I. Since there were still concerns regarding the planning process under the LRP I, the new public engagement component created in this process, which replaced FIT, was not successful in ensuring that all stakeholders who would be most affected would be consulted early and regularly. 


\subsection{Conclusion}

Municipalities and residents criticized the planning process for large-scale wind energy developments that was imposed on them in the FIT policies under the GEA. The FIT policies did not require developers to consult with municipalities or residents, which meant that projects could be approved in municipalities that did not support them. After receiving these criticisms, the Province directed IESO to replace the FIT policies with the LRP process that contained a required consultation component and an optional public engagement component. This was supposed to ensure that developers would have the opportunity to consult with municipalities, residents and Aboriginal communities in the early stages of the planning process, giving municipalities a stronger voice in decisionmaking. To reassure municipalities that their support for a large-scale wind energy project was important, the former Minister of Energy Bob Chiarelli and the Premier of Ontario Kathleen Wynne stated that it would be unlikely that projects would be awarded to municipalities that did not provide support for the project, or in municipalities where the majority of residents were opposed. Unfortunately, the results of this study do not support their statements.

This study sought to determine the degree of compliance with the IESO's public engagement process during LRP I, for the five awarded large-scale wind energy projects. In order to do so, six interviews were conducted with abutting landowners and municipal planners, and document information including a Freedom of Information Request from IESO was reviewed. Results of this study led to four recommendations, shown below.

First, developers should be required to only consult with Aboriginal communities who will be affected by the project, not those who may be interested in it. This would ensure that stakeholders who would be the most affected by the project would have 
impact on the decision-making process. This suggestion has also been recommended by Wind Concerns Ontario (Wind Concerns Ontario, 2016).

Second, the term abutting landowner should be redefined as to only include landowners who are located next to a property that will be host to an industrial wind turbine. Currently, landowners who are located next to a property that will host a connection line may have more influence on the decision-making process than those located next to an industrial wind turbine. The redefinition of the term abutting landowners has been previously suggested by Wind Concerns Ontario as well; however, they believe that the definition is too narrow (Wind Concerns Ontario, 2016), while this study suggests that the definition is too broad.

Third, developers should consult with all stakeholders, including abutting landowners from the start of the planning process. As determined through literature, if developers were to consult with municipalities and residents at the beginning of the planning process for large-scale wind energy developments, acceptance for these projects may increase (Gross, 2007). Studies have also demonstrated that the involvement of residents in the planning process of large-scale wind energy projects could also lead to higher acceptance (MacLaren, 2007; Wright, 2012; Jami \& Walsh, 2016; Corscadden et al., 2012; Brennan \& Van Rensburg, 2016). Recommendations in the literature on how to increase the involvement of residents in the planning process for large-scale wind energy projects include: the use of collaborative planning; local planning and community ownership models (Christidis \& Law, 2012; Songsore \& Buzzelli, 2015; Walker \& Baxter, 2016; MacLaren, 2007). 
Fourth, the rated criteria point system should be changed from an optional component to a required component and should carry more 'weight' in the evaluation process. Municipalities who do not support a project should not have it imposed on them, especially if there are municipalities who are willing to host them. At least 75 municipalities have also requested that in future processes, IESO should only provide contracts to projects that were successful in receiving municipal support (Plevna, 2016).

Although the Province had tried to address criticisms received for the planning process of large-scale wind energy projects in the FIT policies under the GEA, results demonstrated that the optional public engagement component was not a successful method of ensuring early consultation with stakeholders that would be the most affected by the project. 


\section{Appendix A: Interview Questions for Municipal Planners}

\section{Consultation}

1. Has the developer of the wind project consulted ___ (Insert name of municipality/municipalities), during the Large Renewable Procurement (LRP) process?

2. If the (Insert name of municipality/municipalities) were consulted; did the developer initiate the first meeting?

3. Were follow-up meetings conducted with (Insert name of municipality/municipalities)? If so, how many follow-up meetings had been conducted? Who was responsible for arranging these follow-up meetings?

4. Were there other types of meetings held by the developer? For example, were there public meetings?

5. Were information sessions provided by the developer? Did these sessions inform municipalities on the benefits and risks of the proposed project?

6. Was there a Community Liaison Committee established in regards to this project? If yes, who established this committee?

7. Was an agreement proposed, or concluded? If yes, who proposed the agreement?

\section{Effects of this wind power contract (benefits and impacts)}

8. What benefits will receive from the creation of this wind project?

(Insert name of municipality/municipalities),

9. Will the (Insert name of municipality/municipalities), receive a Community Vibrancy Fund?

10. If they have or will receive a Community Vibrancy Fund, is there a plan put in place as to how this money will be distributed?

11. If the municipality is receiving a Community Vibrancy Fund, who suggested it? Was the proposed amount adequate?

12. Do you suspect this wind project will create permanent jobs for the local community?

13. Do you have any remaining concerns about the wind development? 


\section{Position}

14. What was the (Insert name of municipality/municipalities), position in regards to this wind project? Was the municipality in favour of or against this wind project?

15. At the outset, was (Insert name of municipality/municipalities), an official 'unwilling host'? If yes, has that changed?

Note: For each of the five interviews, the name of the municipality will change in the questions. 


\section{Appendix B: Interview Questions for Abutting Landowners}

\section{Consultation}

1. During the Large Renewable Procurement process, were you consulted by the developer in regard to the proposed wind project?

2. If yes, how were you consulted? Through information posted on a flyer, through public meetings? Were you called? Were you visited? Etc.

3. If there were public meetings, do you know how many were held?

4. Did you attend a public meeting?

5. If you did attend a public meeting, how was it conducted?

6. As an abutting landowner, were you able to voice your opinions or concerns through different consultation methods used by the developer? For example: at a public meeting, on an online survey, etc.

7. Were information sessions provided by the developer? Did these sessions inform you on the benefits and risks of the proposed project?

\section{Effects of this wind power contract (benefits and impacts)}

8. Have you gained any benefit, in result of the awarded wind contract?

9. Do you have any remaining concerns about the wind development?

\section{Position}

10. At the beginning, what was your position in regards to this wind project? Were you for or against this project? 


\section{References}

Armeni, C. (2016). Participation in Environmental-Decision making: Reflecting on Planning and Community Benefits for Major Wind Farms. Journal of Environmental Law, 28, 415-441

Baker, L A. (2016). Not backing down on Nation Rise Wind Farm. Retrieved from http://www.standard-freeholder.com/2016/05/02/not-backing-down-on-nation-rise-windfarm

Bieman, J. (2016). Opponents of wind farm planned for Dutton-Dunwich collect 1,822 signatures on petition against the project. Retrieved from http://www.chathamdailynews.ca/2016/11/25/opponents-of-wind-farm-planned-fordutton-dunwich-collect-1822-signatures-on-petition-against-the-project

Brennan, N., \& Van Rensburg, T M. (2016). Wind farm externalities and public preferences for community consultation in Ireland: A discrete choice experiments approach. Energy Policy, 94, 355-365

CANWEA. (n.d. a) Environment and Wildlife. Retrieved from http://canwea.ca/windfacts/environment-wildlife/

CANWEA. (n.d. b) Local Benefits. Retrieved from http://canwea.ca/wind-facts/localbenefits/

CANWEA. (n.d. c). Ontario. Retrieved from www.canwea.ca/wind-energy/ontario

CANWEA. (n.d. d). Why Wind Works. Retrieved from http://canwea.ca/wind-facts/whywind-works/

Christidis, T., \& Law, J. (2012). Annoyance, health effects, and wind turbines: Exploring ontario's planning processes. Canadian Journal of Urban Research, 21(1), 81-105

Corscadden, K., Wile, A., \& Yiridae, E. (2012). Social license and consultation criteria for community wind projects. Renewable Energy, 44, 392-397

EDF. (2017). Romney Wind Energy Centre. Retrieved from http://www.edfen.ca/project/romney-wind-energy-centre/

EDP Renewables. (2017). Nation Rise Wind Farm. Retrieved from http://nationrisewindfarm.com/

Environmental Defence. (2016). Getting FIT: How Ontario Became a Green Energy Leader and Why it Needs to Stay the Course. Retrieved from http://environmentaldefence.ca/report/getting-fit/ 
Evans, B., Parks, J., \& Theobald, K. (2011). Urban wind power and the private sector: community benefits, social acceptance and public engagement

Fast, S., \& Mabee, W. (2015). Place-making and trust-building: The influence of policy on host community responses to wind farms. Energy Policy, 81, 27-37

Fischer, S. (2016). Wind turbines approved for eastern Ontario despite objections. Retrieved from http://www.cbc.ca/news/canada/ottawa/wind-turbine-approved-ontariodespite-objections- 1.3487708

Government of Ontario. (2013). Achieving Balance Ontario's Long-Term Energy Plan. Retrieved from http://www.energy.gov.on.ca/en/files/2014/10/LTEP_2013_English_WEB.pdf

Gross, C. (2007). Community perspectives of wind energy in Australia: The application of a justice and community fairness framework to increase social acceptance. Energy Policy, 35, 2727-2736

Groth, T., \& Vogt, C. (2014). Residents' perceptions of wind turbines: An analysis of two townships in Michigan. Energy Policy, 65, 251-260

Hindmarsh, R. (2010). Wind Farms and Community Engagement in Australia: A Critical Analysis for Policy Learning. East Asian Science, Technology and Society: An International Journal, 4, 541-563

Independent Electricity System Operator. (2015). Request for Proposals for the Procurement of up to $565 \mathrm{MW}$ of New Large Renewable Energy Projects. Retrieved from http://web.ieso.ca/Documents/generation-procurement/lrp/lrp-1-final/LRP-I-RFP.pdf

Independent Electricity System Operator. (2015a). LRP I RFQ - Qualified Applicants. Retrieved from http://www.ieso.ca/Documents/generation-procurement/lrp/LRP-I-RFQQualified-Applicant-List-r6.pdf)

Independent Electricity System Operator. (2015b). LRP I RFP - Registered Proponents List. Retrieved from http://www.ieso.ca/Documents/generation-procurement/lrp/lrp-1final/LRP-I-RFP-Registered-Proponent-List-20150910.pdf

Independent Electricity System Operator. (2016). Freedom of Information and Protection of Privacy Act Request 2016-033; Index of Records and Decision regarding release of Records

Independent Electricity System Operator. (2016a). Large Renewable Procurement II Stakeholder \& Community Engagement 
Independent Electricity System Operator. (2016b). LRP | RFP - Selected Proponents List. Retrieved from http://www.ieso.ca/Documents/generation-procurement/lrp/lrp-1final/LRPI-Selected-Proponent-List-20160412.pdf

Independent Electricity System Operator. (2017). Large Renewable Procurement. Retrieved from http://www.ieso.ca/Sector\%20Participants/Energy\%20Procurement\%20Programs\%20and \%20Contracts/Large\%20Renewable\%20Procurement

Jami, A A., \& Walsh P R. (2016). Wind Power Deployment: The Role of Public Participation in the Decision-Making Process in Ontario, Canada. Sustainability, 8, 1-18

Larsen, J H.M.., Soerensen, H C., Christiansen, E., Naef, S., \& VØlund, P. (n.d.). Experiences from Middelgrunden 40 MW Offshore Wind Farm

Legislative Assembly of Ontario. (2013). Committee Documents: Standing Committee on Justice Policy - 2013 - Nov - 21 - Members' Privileges

Leslie, K. (2009). McGuinty says he won't tolerate 'NIMBYism' in green energy projects. Retrieved from https://www.thestar.com/news/ontario/2009/02/10/mcguinty_says_he_wont_tolerate_nim byism in green energy projects.html

LMWindPower. (n.d.). History of Wind. Retrieved from https://www.lmwindpower.com/en/sustainability/learn-about-wind/history-of-wind

Mabee, W., Mannion, J., \& Carpenter, T. (2012). Comparing the feed-in-tariff incentives for renewable electricity in Ontario and Germany. Energy Policy, 40, 480-489

MacLaren, J. (2007). Wind energy planning in England, Wales and Denmark: Factors influencing project success. Energy Policy, 35, 2648-2660

Manning, P., \& Vince J. (n.d.) Municipalities and the Green Energy Act: Benefits, Burdens, and Loss of Power. Municipal World

Ministry of Energy. (2015). Chapter 3; Section 3.05. Retrieved from http://www.auditor.on.ca/en/content/annualreports/arreports/en15/3.05en15.pdf

Ministry of Energy. (2017). Large Renewable Procurement. Retrieved from http://www.energy.gov.on.ca/en/renewable-energy-development-in-ontario-a-guide-formunicipalities/large-renewable-procurement/

Ohl, C., \& Eichhorn, M. (2010). The mismatch between regional spatial planning for wind power development in Germany and national eligibility criteria for feed-in tariffs A case study in West Saxony. Land Use Policy, 27, 243-254 
Ontario Energy Board. (2016). Historical Electricity Prices. Retrieved from http://www.ontarioenergyboard.ca/OEB/Consumers/Electricity/Electricity+Prices/Histori cal+Electricity+Prices

Ontario Power Authority. (2010). Feed-In Tariff Program. Retrieved from http://fit.powerauthority.on.ca/Storage/11160_FIT_Program_Overview_August_new_pri ce version 1.3.1 final for posting-oct 27.pdf

Ontario Professional Planners Institute. (n.d.) Professional Code of Practice. Retrieved from https://www.cip-icu.ca/Files/Provincial-Codes-of-Conduct/OPPI-ProfessionalCode-of-Practice.aspx

Ontario Public Health Association. (2002). Beyond Coal: Power, Public Health and the Environment. Toronto, Ontario.

Otter Creek Wind Farm. (n.d.). Otter Creek Wind Farm. Retrieved from http://ottercreekwindfarm.ca/

Pepermans, Y., \& Loots, I. (2013). Wind farm struggles in Flanders fields: A sociological perspective. Energy Policy, 59, 321-328

Province of Ontario. (2015). Renewable Energy Development in Ontario: A Guide For Municipalities 2015 Edition. Retrieved from http://www.energy.gov.on.ca/en/files/2016/01/municipal_guide_english_web_2016.pdf

Pushchak, R., Carter-Shamai, S., Golovkin, A., Holmes, K., Jensen, K., Mathuria, S., Wilson, G., \& Windross, E. (2016). Engage or Enrage: A Policy Shift in Ontario's Large Wind Energy Planning. International Conference on Energy, Environment and Economics.

REN21. (2016). Renewables 2016 Global Status Report. (Paris:REN21 Secretariat). Retrieved from http://www.ren21.net/wp-content/uploads/2016/06/GSR_2016_Full_Report.pdf

Renewable Energy Systems Canada Inc. (2017). Eastern Fields. Retrieved from http://www.easternfieldswind.com/welcome

Rowlands, I. (2007). The Development of Renewable Electricity Policy in the Province of Ontario: The Influence of Ideas and Timing. Review of Policy Research, 24(3), 185207

Save The Nation. (n.d.) About Save The Nation. Retrieved from http://www.sauvonslanation.ca/about.html 
Save The Nation. (2015). Report to Independent Electricity System Operator Large Renewable Procurement - Phase I 2015. Retrieved from http://www.sauvonslanation.ca/uploads/3/7/4/9/37493081/report to_lrp_ieso_october_21 2015.pdf

Songsore, E., \& Buzzelli, M. (2015). Wind energy development in Ontario: a process/ product paradox. Local Environment, 20(12), 1428-1451

Stokes, L. (2013). The politics of renewable energy policies: The case of feed-in tariffs in Ontario, Canada. Energy Policy, 56, 490-500

Strong Breeze Wind Power Partnership. (n.d.). Strong Breeze Wind Project. Retrieved from http://strongbreezewind.com/

TerraMetrics Map Data. (2017). Ontario Unwilling Hosts. Retrieved from http://ontariounwilling-hosts.org/ouh-d33.html

Van Brenk, D., \& Miner, J. (2016). Ontario has awarded contracts for five more wind farms. Retrieved from http://www.lfpress.com/2016/03/10/ontario-has-awardedcontracts-for-five-more-wind-farms

Walker, C., \& Baxter, J. (2016). "It's easy to throw rocks at a corporation": wind energy development and distributive justice in Canada. Journal of Environmental Policy and Planning, 1-15

Wind Concerns Ontario. (2016). Re: Input into IESO RFQ and RFP Process Review. Retrieved from http://www.ieso.ca/Documents/consult/LRPII/LRPII-20160330-

WCO.PDF

Wind Energy Foundation. (2016). History of Wind Energy. Retrieved from http://windenergyfoundation.org/about-wind-energy/history/

Wright, Z. (2012). A Voice for the Community: Public Participation in Wind Energy Development. Dalhousie Journal of Interdisciplinary Management, 8, 1-17 